University of Massachusetts Amherst

ScholarWorks@UMass Amherst

Biology Department Faculty Publication Series

Biology

2005

\title{
What is apical and what is basal in plant root development?
}

\author{
F Baluska \\ PW Barlow \\ TI Baskin \\ RJ Chen \\ L Feldman
}

See next page for additional authors

Follow this and additional works at: https://scholarworks.umass.edu/biology_faculty_pubs

Part of the Biology Commons

\section{Recommended Citation}

Baluska, F; Barlow, PW; Baskin, TI; Chen, RJ; Feldman, L; Forde, BG; Geisler, M; Jernstedt, J; Menzel, D; Muday, GK; Murphy, A; Samaj, J; and Volkmann, D, "What is apical and what is basal in plant root development?" (2005). Trends in Plant Science. 20.

https://doi.org/10.1016/j.tplants.2005.07.004

This Article is brought to you for free and open access by the Biology at ScholarWorks@UMass Amherst. It has been accepted for inclusion in Biology Department Faculty Publication Series by an authorized administrator of ScholarWorks@UMass Amherst. For more information, please contact scholarworks@library.umass.edu. 


\section{Authors}

F Baluska, PW Barlow, TI Baskin, RJ Chen, L Feldman, BG Forde, M Geisler, J Jernstedt, D Menzel, GK Muday, A Murphy, J Samaj, and D Volkmann

This article is available at ScholarWorks@UMass Amherst: https://scholarworks.umass.edu/biology_faculty_pubs/20 


\section{What is apical and what is basal in plant root development?}

\section{František Baluška ${ }^{1}$, Peter W. Barlow ${ }^{2}$, Tobias I. Baskin ${ }^{3}$, Rujin Chen ${ }^{4}$, Lewis Feldman ${ }^{5}$, Brian G. Forde ${ }^{6}$, Markus Geisler ${ }^{7}$, Judy Jernstedt ${ }^{8}$, Diedrik Menzel ${ }^{1}$, Gloria K. Muday ${ }^{9}$, Angus Murphy ${ }^{10}$, Jozef Šamaj ${ }^{1}$ and Dieter Volkmann ${ }^{1}$}

${ }^{1}$ Institute of Cellular and Molecular Botany, University of Bonn, Kirschallee 1, 53115 Bonn, Germany

${ }^{2}$ School of Biological Sciences, University of Bristol, Woodland Road, Clifton, Bristol, UK BS8 1 UG

${ }^{3}$ University of Massachusetts, Biology Department, 611 N. Pleasant Street, Amherst, MA 01003, USA

${ }^{4}$ Plant Biology Division, Samuel Roberts Noble Foundation, 2510 Sam Noble Parkway, Ardmore, OK 73401, USA

${ }^{5}$ University of California, Department of Plant and Microbial Biology, 111 Koshland Hall, Berkeley, CA 94720-3102, USA

${ }^{6}$ Department of Biological Sciences, Lancaster University, Lancaster, UK LA1 4YO

${ }^{7}$ Institute of Plant Biology, Molecular Plant Physiology, Zolliker Strasse 107, CH-8007 Zurich, Switzerland

${ }^{8}$ Department of Plant Sciences, Section of Crop and Ecosystems, Mail Stop 1, University of California Davis, One Shields Avenue, Davis, CA 95616-8515, USA

${ }^{9}$ Wake Forest University, Department of Biology, Winston-Salem, NC 27109-7325, USA

${ }^{10}$ Department of Horticulture, Purdue University, 625 Agriculture Mall Drive, West Lafayette, IN 47907, USA 
that apply to most stages of plant development cannot be applied to early zygotic development. Recent introduction of terminology reserved for early embryonic anatomy to post embryonic seedling anatomy have created some confusion. In this letter, we highlight the issue with the intention of clarifying terminology and bringing about a consensus regarding usage.

The original Latin word 'apex' refers to the summit of a hill, mountain or building. According to both the Oxford and Webster dictionaries, 'apex' is defined as 'the highest or topmost point' of a structure. In plants, an apex constitutes the tip of a shoot or a root. The word 'apical', therefore, means relating to, located or situated at, or constituting, an apex.

A 'base' is defined as the 'lowest or bottom part of an object on which it stands' or the 'main part to which other parts are added'. In biology, 'base' means the part of a plant or animal organ that is near the point of attachment to the ground or to a more basal part of the body. Because we cannot say that plants stand on their roots, the base of both stems and roots is actually the same point, and is where the two organs meet and are attached to each other. Similarly, for lateral organs their base refers to their point of attachment to the main plant body: for example, lateral roots are attached at their base to the main root, just as lateral shoots are attached at their base to the stem.

In all standard text books on plant anatomy, including Plant Anatomy, the tips of shoots and roots are referred to as apices (Figure 1) [1]. It is here that their 'apical meristems' are to be found [2]. The attachment point between stem and root is referred to as a base - stem-base or root-base - in each case. Therefore, in roots (possessing their own apex and base, both of which are well defined and instantly recognisable) the proper usage of the term 'apical' can also define the polarity of the constitutent cells and hence direct attention to the cellular pole that faces the apex (or tip). By the same token, 'basal' can refer to the pole that faces the base of the organ (i.e. the basal attachment point of the root to the stem).

The terminology used in several recent publications [3-8] describing the apical pole of the root as facing the root base and its basal pole as facing the root tip conflicts with anatomical conventions. This new and contradictory usage of the terms apical and basal is confusing [9] and we accordingly request that the plant community reach a consensus on this important and fundamental terminology.

A contribution to this confusion has come, in part, from the observation of a dramatic polarity shift in plant (Arabidopsis) embryo development [10]. Because the embryonic suspensor is the tissue in continuity with, and responsible for, the attachment of the early embryo to maternal tissues, it can serve as a reference to define the base of an early embryo. At this stage, the embryo can be correctly inferred to have a single apical-basal axis. However, the suspensor is only a temporary structure and dies during late embryogenesis, whereupon the embryo is no longer attached to maternal tissue. This event coincides with a dramatic change in the organization of the axis, both morphologically and in terms of auxin movement [5], of the now independent embryo which converts from being unipolar to being bipolar. It is important to appreciate that, at this stage, the two opposite apices of root and shoot

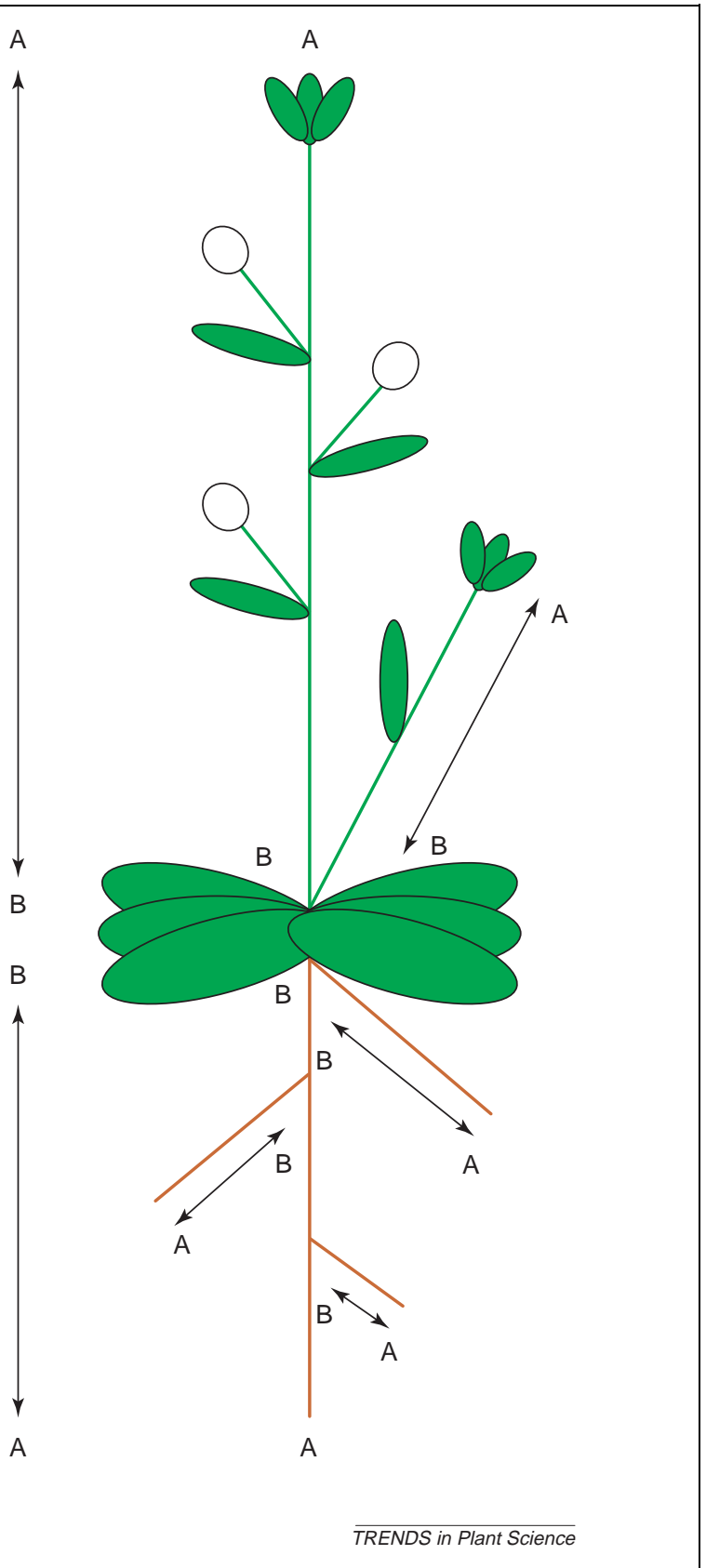

Figure 1. Plant apices and bases. Scheme of a plant (e.g. Arabidopsis) to indicate the apices (A) and bases (B) of its two principal vegetative organ systems: the root system (brown) and the shoot system (green). The base of the main root attaches to the base of the shoot and vice versa. The double-headed arrows indicate the acropetal (arrows pointing towards the apices, A) and basipetal (arrows pointing towards the bases, B) directions.

are connected at a common base. This new bilateral apicalbasal polarity of the late embryo persists and is the same polarity as that which prevails in seedlings and mature plants (Figure 1). With the establishment of every new apical meristem and the resulting branching and development of lateral organs (lateral buds and lateral root meristems), new apical-basal axes are continually added to the preexisting framework (Figure 1).

The above definition of apex and base also affects the related terms 'acropetal' and 'basipetal' (Figure 1). Acropetal refers to the direction of development (such as lateral root primordia or flower development) or the movement of 
substances (such as hormones) in the direction of the apex, whereas basipetal refers to the direction of development or movement towards the base.

We suggest that the terms 'apical' and 'basal' as well as the directional terms 'acropetal' and 'basipetal' be used in all cases after the initiation of embryonic root-shoot polarity. When these terms are applied to the early embryo and suspensor, the maternal-zygotic definitions of polarity should be used. However, we strongly suggest that it creates too much confusion to use the zygotic terminology later in development.

\section{References}

1 Esau, K. (1965) Plant Anatomy, 2nd edn, John Wiley \& Sons

2 Clowes, F.A.L. (1961) Apical Meristems, Blackwell Scientific Publications
3 Friml, J. et al. (2002) AtPIN4 mediates sink-driven auxin gradients and root patterning in Arabidopsis. Cell 108, 661-673

4 Grebe, M. et al. (2002) Cell polarity signaling in Arabidopsis involves a BFA-sensitive auxin influx pathway. Curr. Biol. 12, 329-334

5 Friml, J. et al. (2003) Efflux-dependent auxin gradients establish the apical-basal axis of Arabidopsis. Nature 426, 147-153

6 Friml, J. et al. (2004) A PINOID-dependent binary switch in apicalbasal PIN polar targeting directs auxin efflux. Science 306, 862-865

7 Grebe, M. (2004) Ups and downs of tissue and planar polarity in plants. BioEssays 26, 719-729

8 Blilou, I. et al. (2005) The PIN auxin efflux facilitator network controls growth and patterning in Arabidopsis roots. Nature 433, 39-44

9 Sauer, M. and Friml, J. (2004) The matryoshka dolls of plant polarity. Development 131, 5774-5775

10 Jürgens, G. (2001) Apical-basal pattern formation in Arabidopsis embryogenesis. EMBO J. 20, 3609-3616

1360-1385/\$ - see front matter (c) 2005 Elsevier Ltd. All rights reserved. doi:10.1016/j.tplants.2005.07.004 